\author{
JUSTYNA MIELCZAREK-MIKOŁAJÓW \\ ORCID: 0000-0001-8706-2930 \\ Uniwersytet Wrocławski \\ Instytut Nauk Administracyjnych \\ Zakład Ustroju Administracji Publicznej
}

\title{
ZASADY PRAWIDŁOWEJ LEGISLACJI W KONTEKŚCIE AKTÓW PRAWA WEWNĘTRZNEGO
}

\begin{abstract}
Abstrakt: Z reguły racjonalnego prawodawcy wynika tworzenie racjonalnego prawa zarówno powszechnie, jak i wewnętrznie obowiązującego. Tego wymogu nie spełnia akt, który narusza zasady określone w Konstytucji i tym samym nie odpowiada zasadzie demokratycznego państwa prawa i zasady prawidłowej legislacji. Autorka w niniejszym artykule rozważy orzecznictwo Trybunału Konstytucyjnego, sądów administracyjnych i powszechnych w celu udzielenia odpowiedzi na pytanie, czy praktyka wydawania aktów wewnętrznych wskazuje na zachowanie opisanych zasad konstytucyjnych.
\end{abstract}

Słowa kluczowe: akty prawa wewnętrznego, racjonalny prawodawca, zasada prawidłowej legislacji, zasada demokratycznego państwa prawa

Z perspektywy organów administracji publicznej ${ }^{1}$ to konkretna norma tworzy wzorzec postępowania, w stosunku do którego podlegają ocenie wszystkie działania konkretnego podmiotu. Wzorzec ten jest konstruowany przez racjonalnego prawodawcę przede wszystkim na podstawie przepisów konstytucji, ustaw i poglądów doktryny ${ }^{2}$. Tworzenie prawa jest zaś niejednokrotnie utożsamiane

${ }^{1}$ Za J. Bociem rozumianej jako „człowiek lub grupa ludzi w przypadku organu kolegialnego, znajdujący się w strukturze państwa lub samorządu terytorialnego, powołany w celu realizacji norm prawa administracyjnego, w sposób i ze skutkami właściwymi temu prawu, działający w granicach przyznanych mu przez prawo kompetencji” — idem, Organizacja prawna administracji, [w:] Prawo administracyjne, red. J. Boć, Wrocław 2004, s. 135.

2 Zob. K. Opałek, J. Wróblewski, Zagadnienia teorii prawa, Warszawa 1969, s. 191; I. Lipowicz, Kilka uwag w sprawie racjonalności administracji, [w:] Racjonalny prawodawca: racjonalna administracja. Pamięci profesora Eugenniusza Smouktunowicza, red. D. Kijowski, A. Miruć, A. Budnik, Białystok 2016, s. 63-64; A. Panasiuk, Racjonalny prawodawca a racjonalna administracja - uwag kilka, [w:] Racjonalny prawodawca..., s. 81. 
z wyrażeniem woli przez prawodawcę ${ }^{3}$. Choć główny ciężar jego stanowienia spoczywa na ustawodawcy, to pojęcie legislacji administracyjnej odnosi się do aktów normatywnych tworzonych przez organy administracji publicznej, mających zarówno charakter powszechny, jak i wewnętrzny ${ }^{4}$. Dlatego też podstawową perspektywą w kontekście poruszonej tematyki badawczej jest proces stanowienia prawa ${ }^{5}$, który uznaje się za jedną z form prawotwórstwa i obejmuje nią wydawanie aktów prawnych zawierających normy generalne i abstrakcyjne przez uprawnione do tego podmioty władzy 6 .

Choć zagadnienie racjonalnego prawodawcy odnosi się przede wszystkim do sposobu wykonywania zadań w celu osiągnięcia wytyczonych celów ${ }^{7}$, to z formalnego punktu widzenia jest ono również związane z regułami tworzenia aktów prawnych. Gdy zatem prawodawca przekroczy zakres swobody regulacyjnej, dochodzi do przełamania reguł działania racjonalnego normodawcy i domniemania zgodności aktu z konstytucją. W tym kontekście trudno mówić o zachowaniu reguł racjonalnego tworzenia prawa ${ }^{8}$. Taka konstatacja wymaga podkreślenia w odwołaniu do zasady demokratycznego państwa prawa określonej w art. 2 Konstytucji RP9 , która $\mathrm{z}$ kolei stanowi podstawę wyróżnienia innych zasad, w tym zasady zaufania obywatela do państwa i stanowionego przez to państwo prawa oraz zasady prawidłowej czy też przyzwoitej legislacji ${ }^{10}$. $\mathrm{Z}$ tego powodu warto pochylić się nad drugą ze wskazanych zasad (to jest zasadą prawidłowej legislacji), określaną jako pewien zbiór wzajemnie powiązanych reguł, kształtowanych szczególnie przez orzecznictwo Trybunału Konstytucyjnego ${ }^{11}$. Takie stanowisko podkreśla wyrok Trybunału z dnia 17 maja 2005 roku $^{12}$, z którego wynika, iż racjonalizm stanowienia prawa jest komponentem zasady przyzwoitej (czy inaczej prawidłowej) legislacji unormowanej w art. 2 Konstytucji RP: „Legislacja

${ }^{3}$ Szerzej zob. J. Wróblewski, Zasady tworzenia prawa, Łódź 1979, s. 50-52.

${ }^{4}$ Zob. T. Bąkowski, Niedoskonatości legislacji administracyjnej (przykłady, konsekwencje, źródła i poszukiwanie sposobów sanacji), [w:] Prawo administracyjne dziś i jutro, red. J. Jagielski, M. Wierzbowski, Warszawa 2018, s. 573-574; por. A. Panasiuk, op. cit., s. 81.

${ }^{5}$ Zob. P. Kantor-Kozłowski, Racjonalność prawodawcy jako paradygmat nauk prawnych, „Folia Iuridica Universitatis Wratislaviensis” 9, 2018, nr 1, s. 95-96.

${ }^{6}$ I. Zachariasz, Prawo w ujęciu strukturalnym, Warszawa 2016, s. 150.

${ }^{7}$ I. Lipowicz, op. cit., s. 64-66; K. Opałek, J. Wróblewski, op. cit., s. 194.

8 J. Zaleśny, Zasady prawidłowej legislacji, „Studia Politologiczne” 13, 2009, s. 3, http:// biblioteka.oapuw.pl/jacek-zalesny-zasady-prawidlowej-legislacji-studia-politologiczne-vol-13/ (dostęp: 10.02.2020).

${ }^{9}$ Dz.U. Nr 78, poz. 483 z późn. zm.

10 Zob. J. Oniszczuk, Prawo do dobrej demokracji i zasada zaufania jednostki do państwa, [w:] Dziesięć lat Konstytucji Rzeczypospolitej Polskiej, red. E. Gdulewicz, H. Zięba-Załucka, Rzeszów 2007, passim; wyrok TK z dnia 12 września 2005 roku, sygn. SK.13/05, OTK ZU nr 8/A/2005, poz. 91 , s. 1078 .

${ }^{11}$ Np. K. Działocha, T. Zalasiński, Zasada prawidłowej legislacji jako podstawa kontroli konstytucyjności prawa, „Przegląd Legislacyjny” 2006, nr 3, s. 5-6.

12 Sygn. P 6/04, Legalis nr 68616. 
nieracjonalna nie może być w demokratycznym państwie prawa uznana za »przyzwoitą«, choćby spełniała wszystkie formalne kryteria (na przykład w zakresie formy aktu czy trybu jego ogłaszania)".

Kontynuując ten wątek, warto podkreślić, że zasada prawidłowej legislacji dąży do ustalania prawa w sposób poprawny, precyzyjny i jasny, z uwzględnieniem formułowania praw i obowiązków adresatów w sposób dla nich zrozumiały ${ }^{13}$. Ujmując wskazaną kwestię precyzyjniej, chodzi o niezaskakiwanie adresatów nowymi rozwiązaniami normatywnymi, co jest z kolei powiązane z: ustalaniem odpowiedniego vacatio legis, poszanowaniem praw nabytych, niedziałaniem prawa wstecz czy określonością przepisów prawa ${ }^{14}$. Na tym tle nie budzi wątpliwości, że przestrzeganie zasad prawidłowej legislacji pozostaje aktualne w kontekście całego procesu tworzenia prawa ${ }^{15}$. Takie stanowisko zwraca uwagę na akty prawa wewnętrznego, tworzące interesującą, choć stosunkowo rzadko rozpatrywaną przestrzeń badawczą. W przeszłości akty te, jak można przypuszczać, z nutką ironii nazywano prawem powielaczowym, postrzegając je zarazem jako zjawisko niebezpieczne dla porządku prawnego, powodujące negatywne skutki społeczne ${ }^{16}$.

Model aktu wewnętrznego został ustalony w art. 93 Konstytucji RP. Z pewnym uproszczeniem za jego podstawowe cechy można uznać: wewnętrzny charakter, obowiązywanie jedynie w stosunku do podmiotów podporządkowanych organizacyjnie podmiotowi wydającemu akt oraz istnienie upoważnienia do jego wydawania w postaci przepisu ustawy ${ }^{17}$. Akty prawa wewnętrznego tworzą katalog otwarty, zarówno pod kątem przedmiotowym, jak i podmiotowym. Do wydawania aktów prawa wewnętrznego kompetentny jest „każdy organ władzy publicznej, o ile tylko istnieją »jednostki organizacyjnie podporządkowane «"18, pod kątem zaś formy mogą przybierać postać zarówno uchwały czy zarządzenia, jak $i$ aktu prawnego o innej nazwie, na przykład statutu lub regulaminu ${ }^{19}$.

Mając na uwadze zakres przedmiotowy dalszych rozważań, należy wspomnieć, iż pojęcie podporządkowania organizacyjnego ściśle odnosi się do rodzaju

${ }^{13}$ Wyrok TK z dnia 11 stycznia 2000 roku, sygn. K 7/99, Legalis nr 46353; wyrok TK z dnia 21 marca 2001 roku, sygn. K 24/00, Legalis nr 49669.

${ }^{14}$ H. Izdebski, Elementy teorii i filozofii prawa, Warszawa 2011, s. 286.

15 A. Bator, A. Kozak, Prawodawca racjonalny, [w:] Wprowadzenie do nauk prawnych. Leksykon tematyczny, red. A. Bator, Warszawa 2016, s. 35-38.

${ }^{16}$ J. Jabłońska-Bonca, Prawo powielaczowe. Studium z teorii państwa i prawa, Gdańsk 1987, s. 3 n.

${ }^{17}$ Szerzej zob. P. Winczorek, Komentarz do Konstytucji Rzeczypospolitej Polskiej z dnia 2 kwietnia 1997 r., wyd. 2 rozsz., Warszawa 2008, s. 217-219; W. Płowiec, Koncepcja aktu prawa wewnętrznego w Konstytucji RP, Poznań 2006, s. 47-60; A. Bień-Kacała, Źródła prawa wewnętrznego w Konstytucji Rzeczpospolitej Polskiej z 1997 roku, Toruń 2013, s. 175-246.

18 Zob. wyrok TK z dnia 19 października 2010 roku, sygn. K 35/09, Legalis nr 254426; wyrok SN z dnia 27 listopada 2019 roku, sygn. I NSW 243/19, Legalis nr 2261139.

${ }^{19}$ M. Wiącek, Komentarz do art. 93. Uwagi $n r 14$ i 15, [w:] Konstytucja RP, t. 2. Komentarz art. 87-243, red. M. Safjan, L. Bosek, Warszawa 2016, s. 195. 
więzi prawnych łączących podmioty w danym układzie oraz do zależności zawartej w przepisach prawa, wskazując przy tym na rozróżnienie układu hierarchicznego podporządkowania oraz układu zdecentralizowanego ${ }^{20}$. Oznacza to, że akty wewnętrzne nie mogą wpływać na sytuację prawną jednostki, znajdującą się poza strukturą organizacyjną podmiotu wydającego akt ${ }^{21}$. Trzeba dodatkowo zaznaczyć, że doktryna wyraźnie odróżnia od aktów wewnętrznych w przedstawionym rozumieniu akty pozbawione charakteru normatywnego, o charakterze interpretującym, przybierające postać aktów generalnych stanowienia prawa, które nie są aktami prawa wewnętrznego, ale w odniesieniu do których postuluje się stosowanie warunków modelu ustalonego w art. 93 Konstytucji RP22.

Tematyka związana z praktyką funkcjonowania aktów prawa wewnętrznego w kontekście zasad prawidłowej legislacji jest niezmiernie szeroka, dlatego też zawarte w dalszej części pracy rozważania zostaną skoncentrowane na analizie orzecznictwa Trybunału Konstytucyjnego, Sądu Najwyższego, sądów powszechnych i administracyjnych, które wielokrotnie podejmowały tematykę aktów prawa wewnętrznego, zarówno pod względem spełnienia przez te akty wymogów formalnych, jak i merytorycznych. Szczególnie pierwszy kontekst jest wart uwagi, gdyż obejmuje istnienie konstytucyjnej lub ustawowej podstawy do jego wydania oraz zgłębia ewentualne naruszenie zakazu związania aktem wewnętrznym innych podmiotów niż jednostki organizacyjnie podległe organowi wydającemu akt ${ }^{23}$, co wydaje się szczególnie istotne z punktu widzenia zasady prawidłowej legislacji.

$\mathrm{Z}$ tego powodu w tym miejscu nastąpi przedstawienie wybranych orzeczeń Trybunału Konstytucyjnego. Pierwszy z zaprezentowanych wyroków został wydany 11 maja 2004 roku $^{24}$, uwypuklono w nim stanowisko o zakazie stanowienia przez źródła prawa wewnętrznego podstawy decyzji wobec obywateli, osób prawnych, a także innych podmiotów. Jak wynika z lektury tego orzeczenia: „Żadna tak rozumiana »decyzja « nie może być wydana na podstawie przepisu prawa o charakterze wewnętrznie obowiązującym”. Cytowany wyrok dotyczył często pojawiającej się w judykaturze tematyki interpretacji podatkowej i możliwości jej zastosowania jako normatywnej podstawy indywidualnych rozstrzygnięć ${ }^{25}$. W efekcie podjętej analizy Trybunał zanegował taką możliwość. Wykładnia do-

20 J. Jeżewski, Komentarz do art. 93 Konstytucji RP. Uwaga nr 2, [w:] Konstytucje Rzeczypospolitej oraz komentarz do Konstytucji RP z 1997 roku, red. J. Boć, Wrocław 1998, s. 165.

${ }^{21}$ P. Ruczkowski, Koncepcja aktów (źródeł) prawa wewnętrznego w polskim prawie administracyjnym, Kraków 2013, s. 304-307.

${ }^{22}$ T. Przesławski, Wybrane zagadnienia prawoznawstwa. Szkice z propedeutyki prawa, Warszawa 2018, s. 86-87.

${ }^{23}$ K. Działocha, Uwaga nr 8 do art. 93, [w:] Konstytucja Rzeczypospolitej Polskiej. Komentarz, t. 2, red. L. Garlicki, Warszawa 2001, s. 18; wyrok TK z dnia 4 grudnia 2012 roku, sygn. U 3/11, Legalis nr 548647.

24 Sygn. K 4/03, Legalis nr 62947.

${ }^{25}$ Zob. np. wyrok WSA w Warszawie z dnia 26 listopada 2019 roku, sygn. III SA/Wa 792/19, Legalis nr 2270639. 
konywana w ramach interpretacji podatkowej, nawet gdy przyjmuje postać aktu wewnętrznego, może obowiązywać jednostki podległe organizacyjnie organowi wydającemu, lecz nie powinna być traktowana jako prawo ${ }^{26}$.

$\mathrm{Z}$ podobnych względów Trybunał Konstytucyjny w wyroku z dnia 12 grudnia 2005 roku $^{27}$ zakwestionował zarządzenie nr 6 Komendanta Głównego Policji $\mathrm{z}$ dnia 16 maja 2002 roku $^{28} \mathrm{w}$ sprawie uzyskiwania, przetwarzania i wykorzystywania przez policję informacji oraz sposobów zakładania i prowadzenia zbiorów tych informacji, uznając je za niezgodne $\mathrm{z}$ art. 93 Konstytucji RP. Było to związane z zawarciem we wskazanym zarządzeniu przepisów kształtujących sytuację prawną obywateli przez określenie przypadków umożliwiających pobieranie od konkretnych kategorii obywateli odcisków linii papilarnych czy podjęcie innych czynności ingerujących w konstytucyjne prawa obywateli.

Warty uwagi jest również wyrok Trybunału z dnia 18 października 2014 roku $^{29}$, stwierdzający niekonstytucyjność zarządzenia Ministra Spraw Zagranicznych z dnia 4 listopada 1985 roku w sprawie szczegółowego trybu postępowania przed konsulem ${ }^{30}$ po upływie kilkudziesięciu lat jego obowiązywania. Wskazane zarządzenie dotyczyło postępowania przed konsulem, co w ocenie Trybunału zdyskredytowało jego wewnętrzny charakter, gdyż służyło jako podstawa decyzji wobec obywateli, cudzoziemców oraz osób prawnych. Znaczenie pojęcia „decyzja” zostało przy tym określone szeroko i dotyczyło każdego indywidualnego oraz konkretnego aktu prawnego, jeśli tylko będzie kształtował sytuację prawną tych jednostek.

Nieco inny charakter miało orzeczenie Trybunału Konstytucyjnego z dnia 19 października 2010 roku $^{31}$, w konsekwencji którego zmianie uległo brzmienie art. 20 ust. 2 ustawy z dnia 15 lipca 1987 roku o Rzeczniku Praw Obywatelskich $^{32} \mathrm{z}$ uwagi na stwierdzoną niezgodność jego pierwotnej treści z Konstytucją. Z zapisu tego wynikało, że „Zadania i organizację biura określa statut, który nadaje Marszałek Sejmu na wniosek Rzecznika", co ewidentnie wskazywało na podległość organizacyjną Rzecznika w stosunku do Marszałka Sejmu. Trybunał w opisywanym wyroku podkreślił pozycję Rzecznika jako niezawisłego i niezależnego organu państwa, dlatego też wywiódł wniosek o braku jego organizacyjnej podległości i tym samym wykluczeniu możliwości wydawania przez organ Sejmu aktów prawa wewnętrznie obowiązującego, mających wiązać Rzecznika.

26 T. Dębowska-Romanowska, Obliczenie podatku a gwarancje praw obywatelskich, „Państwo i Prawo" 1998, nr 7, s. 28 n.

27 Sygn. K 32/04, Legalis nr 71527.

28 http://www.policja.pl/ftp/dzienniki_urzedowe/2002/dziennik_08_2002.pdf (dostęp: 10.02 2020).

${ }^{29}$ Sygn. K 8/14, Legalis nr 1079557.

${ }^{30}$ M.P. Nr 35, poz. 233.

31 Sygn. K 35/09, Legalis nr 254426.

32 Tekst jedn. Dz.U. z 2018 r. poz. 2179 z późn. zm. 
Z zaprezentowanej analizy orzeczeń Trybunału Konstytucyjnego należy wyciągnąć wniosek o zwróceniu przez Trybunał szczególnej uwagi na bezpośrednie stosowanie aktów prawa wewnętrznego w odniesieniu do jednostek usytuowanych poza strukturą organizacyjną podmiotu wydającego akt.

Na tym tle warto dodać, że akty prawa wewnętrznego podlegały licznej kontroli Sądu Najwyższego, sądów powszechnych i administracyjnych ${ }^{33}$. Poruszona w nich problematyka w większości wypadków dotyczyła także zakazu wydawania, na podstawie źródeł prawa wewnętrznego, decyzji wobec obywateli, osób prawnych oraz innych podmiotów. Nie sposób pominąc uwypuklenia przez judykaturę przypadków, w których akty wydawane w postaci zarządzeń nie spełniały przesłanek określonych w art. 93 Konstytucji RP z uwagi na brak normatywnego charakteru i czysto informacyjno-techniczny, porządkujący czy uściślający charakter, co stanowi efekt stosowania, a nie tworzenia prawa ${ }^{34}$. Podobna uwaga dotyczy pism centralnych organów administracji publicznych, przykładowo pisma Głównego Inspektora Sanitarnego, gdyż podobnie jak zarządzenia nie znalazły się one w katalogu konstytucyjnych źródeł prawa powszechnie obowiązującego, zawartym w art. 87 Konstytucji ${ }^{35}$.

Analizowane przez autorkę orzeczenia, uwypuklające naruszenia procedury tworzenia aktów prawa wewnętrznego, były wydawane w kontekście kontroli rozmaitych rozstrzygnięć, przedmiotowo związanych przykładowo ze: zwrotem dofinansowania realizacji projektu ${ }^{36}$, określeniem składu komisji egzaminacyjnych ${ }^{37}$, ustaleniem równoważnika za brak lokalu mieszkalnego ${ }^{38}$, nałożeniem kary za przejazd środka przewozowego po drogach publicznych bez właściwego zezwolenia ${ }^{39}$ lub z pojazdem nienormatywnym ${ }^{40}$, z nakazaniem wykonania określonych robót budowlanych ${ }^{41}$, zasiłkiem celowym ${ }^{42}$, przyznaniem płatności dla gospodarstwa nisko-

${ }^{33}$ Szerzej o kontroli sądowej zob. J. Boć, Kontrola prawna administracji, [w:] Prawo administracyjne..., s. 391-408.

${ }^{34}$ Wyrok SA w Łodzi z dnia 26 marca 2018 roku, sygn. VIII U 132/18, Legalis nr 2075432.

35 Wyrok WSA w Gdańsku z dnia 12 lutego 2004 roku, sygn. II SA/Gd 754/01, Legalis nr 648378.

${ }^{36}$ Wyrok NSA z dnia 4 września 2019 roku, sygn. I GSK 1280/18, Legalis nr 2265061.

${ }^{37}$ Zob. postanowienie WSA w Warszawie z dnia 19 kwietnia 2018 roku, sygn. VI SA/Wa 1985/18, Legalis nr 1895839.

38 Wyrok WSA w Łodzi z dnia 21 stycznia 2004 roku, Legalis nr 1168338.

${ }^{39}$ Wyrok WSA w Lublinie z dnia 20 maja 2004 roku, sygn. II SA/Lu 1175/03, Legalis nr 1151580.

${ }^{40}$ Wyrok WSA w Olsztynie z dnia 7 października 2004 roku, sygn. II SA/Ol 150/04, Legalis nr 2214359.

${ }^{41}$ Wyrok WSA w Rzeszowie z dnia 4 września 2004 roku, sygn. SA/Rz 1015/02, Legalis nr 312682.

42 Wyrok NSA z dnia 15 lipca 2011 roku, sygn. I OSK 582/11, Legais nr 819955. 
towarowego ${ }^{43}$, przekazaniem własności nieruchomości lub ich części położonych na obszarze Ziem Zachodnich i Północnych na rzecz osób prawnych ${ }^{44}$.

Uzupełniając powyższe, uwagę autorki zwrócił także wyrok WSA w Poznaniu z dnia 6 stycznia $2006^{45}$ roku, w którym sąd uznał Komunikat nr 2 Prezesa Głównego Urzędu Ceł z dnia 18 marca 2002 roku w sprawie ustalania wartości celnej używanych pojazdów samochodowych za niezgodny z Konstytucją RP. Sąd w przywołanej argumentacji określił komunikat jako akt prawa wewnętrznego, wskazując, iż: „Jako akt tzw. prawa wewnętrznego był on bowiem adresowany wyłącznie do jednostek organizacyjnych i ich pracowników podległych Prezesowi Głównego Urzędu Ceł, a zatem podmiotów podporządkowanych mu organizacyjnie”. Pomimo zastosowania formy „komunikatu”, która jest charakterystyczna dla aktów stosowania prawa, analiza treści w nim zawartych doprowadza do przekonania o jego normatywnym charakterze i w konsekwencji aprobaty stanowiska uznającego go za akt prawa wewnętrznego.

Choć niniejszy artykuł skupia uwagę czytelnika przede wszystkim na analizie orzecznictwa, warto uwydatnić zgłaszane w doktrynie wątpliwości co do charakteru wewnętrznego niektórych aktów prawnych. Jednym z takich przykładów jest decyzja dyscyplinarna organów administracji penitencjarnej wydawana w stosunku do więźnia w związku z naruszeniem zasad porządku wewnętrznego, czego konsekwencją są często daleko idące konsekwencje w postaci umieszczenia więźnia w celi izolacyjnej na określony czas. Wątpliwości w opisanej sytuacji wzbudza sposób podporządkowania w stosunku do organów wykonawczych, który jest jednak odmienny od relacji łączącej funkcjonariusza publicznego zatrudnionego w Służbie Więziennej wobec podmiotu kierującego jednostką penitencjarną ${ }^{46}$.

Ukazany problem wpływu aktów prawa wewnętrznego bywa ujmowany w literaturze pod pojęciem „refleksu”, co ma obrazować wpływ, jaki akty wewnętrzne wywierają na sytuację prawną jednostki ${ }^{47}$. Niezależnie od tego analiza praktyki wydawania źródeł prawa wewnętrznego uwypukla ich stanowienie na niewłaściwej podstawie prawnej lub bez jakiejkolwiek podstawy prawnej ${ }^{48}$.

Konkludując, należy zaznaczyć, że z reguły racjonalnego prawodawcy wynika następująca dyrektywa interpretacyjna: jeśli prawodawca jest racjonalny, to

${ }^{43}$ Wyrok WSA w Kielcach z dnia 9 czerwca 2009 roku, sygn. II SA/Ke 291/09, Legalis nr 877628.

${ }^{44}$ Wyrok WSA w Warszawie z dnia 26 kwietnia 2013 roku, sygn. I SA/Wa 377/13, Legalis nr 678600 .

45 Wyrok WSA w Poznaniu z dnia 6 stycznia 2006 roku, sygn. I SA/Po 545/03, Legalis nr 345320.

${ }^{46}$ Prawoznawstwo a praktyka stosowania prawa, red. Z. Tobor, I. Bogucka, Katowice 2002, s. $86-87$.

${ }^{47}$ S. Wronkowska, Analiza pojęcia prawa podmiotowego, Poznań 1973, s. 58 n.

48 Por. J. Kaczor, Zasady państwa prawa a upoważnienia do stanowienia aktów prawnych wewnętrznie obowiązujących, [w:] Rządy prawa i europejska kultura prawna, red. A. Bator, J. Helios, W. Jedlecka, Wrocław 2014, s. $41 \mathrm{n}$. 
i jego dzieło, jakim jest akt normatywny, jest racjonalne. Wymogu tego nie spełnia akt, który narusza zasady określone w Konstytucji i tym samym nie odpowiada zasadzie prawidłowej legislacji. Przeanalizowany przez autorkę dorobek judykatury wskazuje na liczne przypadki, w których prawo wewnętrzne wywiera bezpośredni wpływ na sytuację jednostki. W orzecznictwie wymienione sytuacje były traktowane jako wydanie decyzji wobec obywatela bez wymaganej do tego podstawy prawnej, co z kolei stanowiło przyczynę dalszych konsekwencji procesowych, w tym stwierdzenia nieważności wydanych decyzji ${ }^{49}$.

Zarysowany problem zauważa także doktryna, lecz to zbadanie orzecznictwa uwypukla skalę tak zdefiniowanego zjawiska. Problematyka prawa wewnętrznego jest nośna, a także istotna z praktycznego punktu widzenia, dlatego jej analiza powinna być znacznie częściej podejmowana. Akty prawa wewnętrznego tworzą bowiem zbiór wewnętrznie zróżnicowany, niezwykle obszerny i trudny do zbadania. Analiza dorobku judykatury doprowadza do wniosku o sprzeczności praktyki ich wydania z zasadami racjonalnego tworzenia prawa, prawidłowej legislacji, co nie sprzyja pogłębianiu zaufania obywatela do państwa i tworzonego przez jego organy prawa.

\title{
PRINCIPLES OF PROPER LEGISLATION IN THE CONTEXT OF INTERNAL LAW
}

\begin{abstract}
Summary
The rule of a rational legislator results in the creation of rational law, both universally and internally binding. The above requirement isn't met by an act which violates the principles set out in the Constitution and thus does not comply with the principle of a democratic state of law and the principle of correct legislation. The author of the article will examine the jurisprudence of the Constitutional Tribunal, administrative and common courts in order to answer the question whether the practice of issuing internal acts indicates the application of the above-described constitutional principles.
\end{abstract}

Keywords: acts of internal law, a rational legislator, the principle of correct legislation, the principle of a democratic state of law

\section{BIBLIOGRAFIA}

Bator A., Kozak A., Prawodawca racjonalny, [w:] Wprowadzenie do nauk prawnych. Leksykon tematyczny, red. A. Bator, Warszawa 2016.

Bąkowski T., Niedoskonałości legislacji administracyjnej (przykłady, konsekwencje, źródła i poszukiwanie sposobów sanacji), [w:] Prawo administracyjne dziś i jutro, red. J. Jagielski, M. Wierzbowski, Warszawa 2018.

49 Zob. wyrok NSA z dnia 26 czerwca 2019 roku, sygn. I SA/Gd 514/19, Legalis nr 1975230; wyrok WSA w Opolu z dnia 8 kwietnia 2004 roku, sygn. II SA/Wr 2616/01, Legalis nr 2219772. 
Bień-Kacała A., Źródła prawa wewnętrznego w Konstytucji Rzeczpospolitej Polskiej z 1997 roku, Toruń 2013.

Boć J., Kontrola prawna administracji, [w:] Prawo administracyjne, red. J. Boć, Wrocław 2004.

Boć J., Organizacja prawna administracji, [w:] Prawo administracyjne, red. J. Boć, Wrocław 2004.

Dębowska-Romanowska T., Obliczenie podatku a gwarancje praw obywatelskich, „Państwo i Prawo” $1998, \mathrm{nr} 7$.

Działocha K., Uwaga nr 8 do art. 93, [w:] Konstytucja Rzeczypospolitej Polskiej. Komentarz, t. 2, red. L. Garlicki, Warszawa 2001.

Działocha K., Zalasiński T., Zasada prawidłowej legislacji jako podstawa kontroli konstytucyjności prawa, „Przegląd Legislacyjny” 2006, nr 3.

Izdebski H., Elementy teorii i filozofii prawa, Warszawa 2011.

Jabłońska-Bonca J., Prawo powielaczowe. Studium z teorii państwa i prawa, Gdańsk 1987.

Jeżewski J., Komentarz do art. 93 Konstytucji RP. Uwaga nr 2, [w:] Konstytucje Rzeczypospolitej oraz komentarz do Konstytucji RP z 1997 roku, red. J. Boć, Wrocław 1998.

Kaczor J., Zasady państwa prawa a upoważnienia do stanowienia aktów prawnych wewnętrznie obowiazujacych, [w:] Rzady prawa i europejska kultura prawna, red. A. Bator, J. Helios, W. Jedlecka, Wrocław 2014.

Kantor-Kozłowski P., Racjonalność prawodawcy jako paradygmat nauk prawnych, „Folia Iuridica Universitatis Wratislaviensis" 9, 2018, nr 1.

Lipowicz I., Kilka uwag w sprawie racjonalności administracji, [w:] Racjonalny prawodawca: racjonalna administracja. Pamięci profesora Eugenniusza Smouktunowicza, red. D. Kijowski, A. Miruć, A. Budnik, Białystok 2016.

Opałek K., Wróblewski J., Zagadnienia teorii prawa, Warszawa 1969.

Oniszczuk J., Prawo do dobrej demokracji i zasada zaufania jednostki do państwa, [w:] Dziesięć lat Konstytucji Rzeczypospolitej Polskiej, red. E. Gdulewicz, H. Zięba-Załucka, Rzeszów 2007.

Panasiuk A., Racjonalny prawodawca a racjonalna administracja — uwag kilka, [w:] Racjonalny prawodawca: racjonalna administracja. Pamięci profesora Eugenniusza Smouktunowicza, red. D. Kijowski, A. Miruć, A. Budnik, Białystok 2016.

Płowiec W., Koncepcja aktu prawa wewnętrznego w Konstytucji RP, Poznań 2006.

Prawoznawstwo a praktyka stosowania prawa, red. Z. Tobor, I. Bogucka, Katowice 2002.

Przesławski T., Wybrane zagadnienia prawoznawstwa. Szkice z propedeutyki prawa, Warszawa 2018.

Ruczkowski P., Koncepcja aktów (źródet) prawa wewnętrznego w polskim prawie administracyjnym, Kraków 2013.

Wiącek A., Komentarz do art. 93. Uwagi nr 14 i 15, [w:] Konstytucja RP, t. 2. Komentarz art. 87-243, red. M. Safjan, L. Bosek, Warszawa 2016.

Winczorek P., Komentarz do Konstytucji Rzeczypospolitej Polskiej z dnia 2 kwietnia 1997 r., wyd. 2 rozsz., Warszawa 2008.

Wronkowska S., Analiza pojęcia prawa podmiotowego, Poznań 1973.

Wróblewski J., Zasady tworzenia prawa, Łódź 1979.

Zachariasz I., Prawo w ujęciu strukturalnym, Warszawa 2016.

Zaleśny J., Zasady prawidłowej legislacji, „Studia Politologiczne” 13, 2009 http://biblioteka.oapuw.pl/ jacek-zalesny-zasady-prawidlowej-legislacji-studia-politologiczne-vol-13/(dostęp: 10.02.2020). 